\title{
The Impairment of Long-Lived Assets and Reversing Revaluation Review under US GAAP VS. IFRS Models in the United States
}

\author{
Karina Kasztelnik ${ }^{1}$ \\ ${ }^{1}$ Chair, Dissertation Committee, Professor Accounting \& Tax, Grand Canyon University - College of Doctoral \\ Studies - DC Network, United States \\ Correspondence: Karina Kasztelnik, Chair, Dissertation Committee, Professor Accounting \& Tax, Grand Canyon \\ University - College of Doctoral Studies - DC Network, United States. E-mail: karinakasztelnik@yahoo.com
}

Received: July 4, 2015

Accepted: August 7, 2015

Online Published: August 10, 2015

doi:10.5430/afr.v4n3p106

URL: http://dx.doi.org/10.5430/afr.v4n3p106

\begin{abstract}
The impairment valuation of assets plays a central role in the accounting and operating decisions of the multinational companies. Although these techniques based on a similar theory, they may generate different results in the application. This study incorporates an empirical approach to compare the outcomes of the two valuations: under US GAAP and IFRS (International Financial Reporting Standards). The aim of this study it to make the observation whether these valuation methods result in different values and to contribute to the understanding of why these two valuations under US GAAP and IFRS, although similar in theory, may generate different results when applied to real life companies. Also, this study includes the discussion about what kind of the management decision should make CEO before the first-time adoption IFRS in the U.S.A from management accounting perspective. This article will help the audience, develop and internalize a model for making business judgments. Finally, this article should particularly address how impairments made under IAS 36 viewed by investors, how economic incentives drive the decision to impairment, and the increasingly important role the international auditors or management accountants play in verifying something almost unverifiable.
\end{abstract}

Keywords: Impairment, Long-Lived Assets, Reversing Revaluation, IFRS, US GAAP

\section{Introduction}

Under U.S. GAAP, a long-lived asset or group of long-lived assets must be re-measured for possible impairment whenever events or changes in circumstances indicate that the carrying values may not be recoverable. An example of such events or changes in circumstances includes the following:

- Significance physical change in an asset,

- Significance decrease in the market value of an asset,

- Accumulation of costs significantly in excess of the amount originally expected to acquire

An impairment loss should recognize when the aggregate of estimated future cash flows less estimated future cash outflows to be generated by an asset is less than the asset's carrying value. Future cash inflows include an estimate of the proceeds from eventual disposition. For purposes of this comparison, estimated future cash flows are determined without reference to the researcher's discounted present value.

Under IFRS, an impairment occurs when the carrying value of an asset exceeds its recoverable amount. The recoverable amount represents the amount of cash that an asset will generate either through the use (value in use) or through disposal (fair value less costs to sell). Fair value less costs to sell is the amount obtained for an asset in an arm's length transaction between knowledgeable, willing parties, less the cost of disposal. The fair value of used assets with no active market will have to estimate.

The impairment reviews are following:

- At each reporting date, a company should assess whether there are any indications that an impairment has occurred,

- If there are such indications, then the recoverable amount of the asset must be estimated, 
- For example, intangible assets with indefinite lives should be reviewed for impairment annually. The review should take place at the same time each year,

- Cash generating units that include goodwill may be reviewed for impairment annually.

To conclude, ASC 360-10-35-21 requires a review for impairment indicators in PP\&E whenever events or changes in circumstances indicate that the carrying amount of an asset may not be recoverable. IAS 36 requires, an entity to assess annually whether there is any indicator of impairment. This article will focus on a reversal of the impairment loss under U.S. GAAP and IFRS and impact on the financial statement.

Under U.S. GAAP, the impairment loss from a periodic valuation is always reported through net income. Under IFRS is recognized in other comprehensive income to the extent that it is reversing a prior upward valuation. Otherwise, it is included in net income. A reversal is of the impairment loss is prohibited in U.S. GAAP, but under IFRS the impairment loss can reverse up to the newly calculated recoverable amount, but it cannot exceed what the original carrying amount, net of depreciation, would have been.

\section{Purposes of the Study}

The purpose of this case study is to understand the impairment of Long-Lived Assets and Reversing a Prior Upward Revaluation review under US GAAP vs. IFRS Models in the United States for the individual groups.

\section{Research Questions}

The following research questions will guide this study:

1) How do we recognize impairment losses for assets other than goodwill under IFRS and U.S. GAAP?

2) When and how do we reverse an impairment loss under IFRS?

3) Can we reverse a goodwill impairment loss under IFRS?

\section{Review of Related Literature}

\subsection{Prior Studies on Impairments of Long-Lived Assets}

The literature is rich with papers examining the impairment of long-lived assets. One of the earliest studies on impairments of long-lived assets under the Accounting Standards Council (ASC) and International Financial Reporting Standards (IFRS) is by Komissarov, Kastantin, and Rick (2014). They discussed include the factors under ASC Topic 350 and ASC Topic 360 that are significant to long-lived assets and methods used by the IFRS and ASC in determining whether an asset is impaired or not, and the disclosure requirements set by these standards.

Another study by Chalmers, Clinch, Godfrey, and Wei (2012) investigated whether the adoption of International Financial Reporting Standards (IFRS) in 2005 by Australian firms associated with a loss of potentially useful information about intangible assets. The authors found that the negative association between the accuracy and dispersion of analysts' earnings forecasts and aggregate reported intangibles previously documented by Matolcsy and Wyatt (2006) becomes stronger subsequent to IFRS adoption primarily for firms with high levels of underlying intangible assets. Also, the author's result of the study is largely attributable to reported goodwill valuation required by IFRS conveys more useful information than does the former straight-line amortization approach. As a result of the study of convergence, Homan (2004) found that some companies are surprised to learn that the conversion to international standards will not eliminate all differences between IFRS financial statements and those prepared under U.S. Generally Accepted Accounting Principles.

\subsection{The implication of Impairment Reversals}

Trottier (2013) conducted his research study; IAS No. 36 permits an impairment loss on a long-lived asset to reverse if the economic value of the asset recovers. He used empirical data from an experiment conducted with 118 managers to explore the implication of impairment reversals on a manager's decision to record a loss. Sevin and Schroeder (2005) find evidence to suggest that some firms used the adoption of the policy in a "big bath" strategy. Ramanna (2008) finds evidence that underestimated goodwill impairments associate with managerial incentives. However, Jarva (2009) finds no agency-based motives for the pattern of goodwill write-offs in his paper and concludes that these impairments are more closely related to economic factors than to opportunistic motives. The ASC and IFRS contain requirements for entities that assess for impaired assets but subsequently determine that the assets not impair. In these instances, the ASC and IFRS require the entity to reassess all of the depreciation or amortization variables to determine whether these estimates remain appropriate. The rates, useful lives, estimated salvage values, and methods used to calculate depreciation and amortization have a direct bearing on whether an asset's carrying amount is likely to 
exceed its recoverable amount. For impairment assessments that include goodwill, the ASC requires testing to occur at the reporting-unit level, which is the operating segment or one level below the segment.

\subsection{Goodwill - Prior Research Studies}

IFRS requires goodwill to allocate to all CGUs (or groups of CGUs) to which the goodwill relates. Such allocations cannot be higher than the segment level and often made at a lower level. The ASC has one measurement to compare with the potentially impaired asset's carrying amount: the asset's fair value. The impairment loss is any excess of the asset's carrying amount over its fair value. IFRS has two measurements to compare with the carrying amount of a potentially impaired asset: value in use and fair value less costs of disposal (FVLCD). The higher of these two measurements is compared with the carrying amount to determine any impairment loss. The deduction of the costs of disposal from fair value under IFRS could result in an additional measurement difference (Komissarov, 2014). Kuzmina \& Kozlovska (2012) did the evaluation of long-lived assets is regulated by the national accounting laws and international financial reporting standards, in particular IAS 36 "Impairment of Assets". The authors stated that many questions related to the practical application remain unresolved and lead to different interpretations and subjective judgments. Therefore, I found the gap that some cases shareholder' expectations of future economic benefits from the use of long-lived assets fulfilled. Huian (2013) presented exploratory evidence about standard setters' response to this challenge by examining whether Statement of Financial Standards No. 142 (SFAS 142): Goodwill and Other Intangible Assets altered the information content of goodwill write-offs. The author documented a negative and significant stock market reaction to unexpected goodwill write-offs. He did not find any variation in market reaction based on firm complexity.

\subsection{The Impairment Write-Offs Approach in the Historical Studies}

Riedl (2014) found a higher association between write-offs and "big bath" reporting behavior after the standard's implementation, and that this "big bath" behavior more likely reflected opportunistic reporting by managers rather than the provision of their private information. The author suggested the reporting of write-offs under SFAS No. 121 had decreased in quality, consistent with criticisms of the standard. Godfrey (2010) found that impairment write-offs negatively associated with firms' underlying investment opportunities. He also found associations between goodwill impairment write-offs and traditionally applied leverage, firm size and returned on assets variables, although the leverage and firm size results are less robust. Finally, his results support the International Accounting Standards Board and Financial Accounting Standards Board contention that an impairment test regime can reflect firm's underlying economic attributes, while the managers use direction to reduce contracting costs. This study (Beatty \& Weber, 2010) examined Statement of Financial Accounting Standards 142 adoption decisions, focusing on the trade-off between recording certain current goodwill impairment charges. They found evidence suggesting that firms' equity market concerns affect their preference for above-the-line vs. below-the-line accounting treatment, and firms' debt contracting.

\section{Methodology - Qualitative Data Collection}

The researcher is the instrument. She has a unique direct international accounting experience in the European Union and the United States on the accounting executive level. 


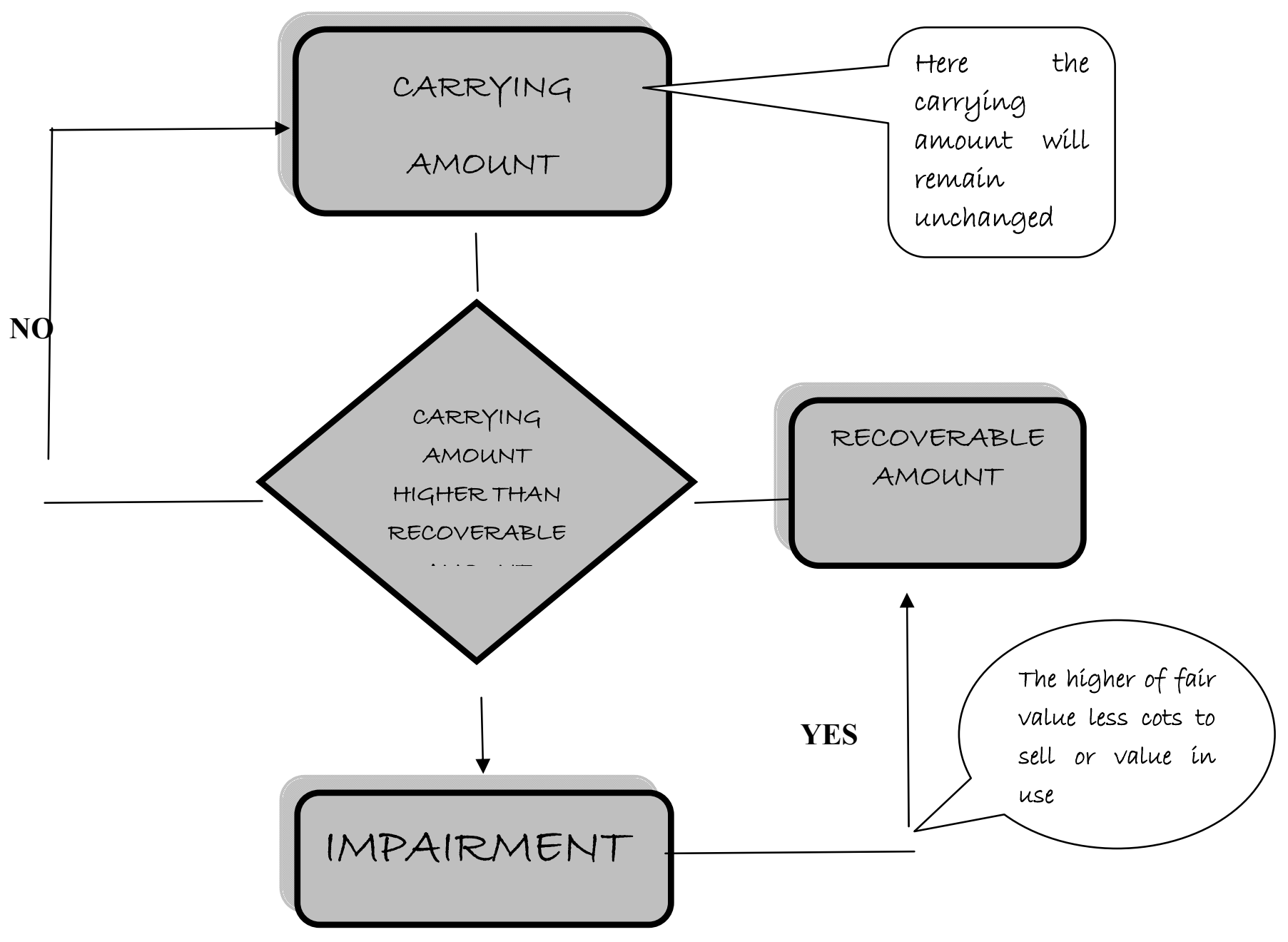

Impairment - General Process

Source: Compiled by Author

The impairment assesses at each reporting date whether there is an indication that an asset may be impaired. The recoverable amount is determined for each asset unless the asset generates cash inflows that are not largely independent of those from other assets or groups of assets (cash-generating units). If the carrying amount of an asset of a cash-generating unit exceeds the recoverable amount, an impairment loss is recognized for the difference. The recoverable amount is the higher of fair value less costs to sell and value in use. In a first step determines the respective recoverable amount as a value in use and compares it with the respective carrying amounts including goodwill. If the value in use is lower than the carrying amount, fair value less costs to sell are additionally calculated to determine the recoverable amount.

\section{Qualitative Data Analysis}

This research will rely on a qualitative approach. Accounting-based reporting data will use to conduct the observational research study. This study seeks to understand the phenomena impairment long-term assets from US GAAP and IFRS point of view, therefore, making a qualitative approach plausible. The population is over one hundred financial statements from the international companies. The researcher will read all financial statements and conduct the data analysis then complied the data in one sample to explain the major differences in impairment and reversal of assets within this study. 


\section{Data Collection}

\subsection{Computer Modelling Group Ltd.}

CMG is a computer software technology company serving the oil and gas industry. The Company is a leading supplier of advanced processes reservoir modelling software with a blue chip customer base of international oil companies and technology centers in approximately 60 countries. The Company also provides professional services consisting of highly specialized support, consulting, training, and contract research activities. CMG has sales and technical support services based in Calgary, Houston, London, Caracas, Dubai, Bogota and Kuala Lumpur. CMG's Common Shares listed on the Toronto Stock Exchange ("TSX") and trade under the symbol "CMG" (CMG, 2015).

\subsection{Impairment of Long-Lived Assets Approach under IFRS (International Financial Reporting Standards)}

The carrying amounts of the Company's non-financial assets, other than deferred tax assets, are reviewed at each reporting date to determine whether there is any indication of impairment. If any such indication exists, then the asset's recoverable amount is estimated, and any impairment loss required is recognized in the statement of comprehensive income. An impairment loss is reversed only to the extent that the asset's carrying amount does not exceed the carrying amount that would have been determined, net of depreciation, if no impairment loss recognized (CMB, 2015).

Property and equipment recorded at cost less accumulated depreciation. Cost includes expenditures that are directly attributable to the acquisition of the asset. Depreciation is based on the cost of an asset and is recognized from the date the item is ready for use in the statement of comprehensive income using the following annual rates and methods that are expected to amortize the cost of the property and equipment over their estimated useful lives:

Table 1. CMG - Significant Accounting Policies - Property and Equipment

Computer Equipment $\quad 331 / 3 \%$ straight-line

Furniture and Equipment $\quad 20 \%$ straight-line

Leasehold Improvements Straight-line over the lease term

Source: Compiled by Author

Under IFRS the company, any gain or loss on disposal of an item of property and equipment (calculated as the difference between the net proceeds from disposal and the carrying amount of the item) is recognized in the statement of comprehensive income. The estimated useful lives and depreciation methods are reviewed at each fiscal year-end and adjusted if appropriate.

\subsection{GRACO Inc.}

Graco Inc., is a multi-national manufacturing company. The company designs, manufactures and market equipment to pump, meter, mix and dispense a wide variety of fluids and coatings. The equipment used in the construction, automotive, industrial, mining, oil and natural gas, process, public works and other industries (GRACO, 2015).

\subsection{Impairment of Long-Lived Assets Approach under US GAAP}

The Company evaluates long-lived assets (including property and equipment, goodwill and other Intangible assets) for impairment whenever events or changes in business circumstances indicate the carrying value of the assets may not be recoverable. Goodwill and other intangible assets not subject to amortization are also reviewed for impairment annually in the fourth quarter. There were no write-downs of long-lived assets in the periods presented.

For financial reporting purposes, plant and equipment are depreciated over their estimated useful lives, primarily by using the straight-line method as follows: 
Table 2. Property, Plant, and Equipment

Buildings and Improvements $\quad 10-30$ years

Leasehold Improvements lesser of 5 to 10 years or life of lease

Manufacturing Equipment

lesser of 5 to 10 years or life of equipment

Office, warehouse and automotive equipment $\quad 3$ to 10 years

Source: Compiled by Author

The Company performs impairment testing for goodwill and other intangible assets annually, or more frequently if events or changes in circumstances indicate that the asset might be impaired. For goodwill, the Company performs impairment reviews for the Company's reporting units using a fair-value method based on management's judgments and assumptions. The Company estimates the fair value of the reporting units by an allocation of the market capitalization value, crosschecked by a present value of the future cash flows calculation. The estimated fair value then compared with the carrying amount of the reporting unit, including recorded goodwill. Based on our most recent goodwill impairment assessment performed during the fourth quarter of 2014, the fair value of each reporting unit significantly exceeded its carrying value, except for the businesses acquired in 2014. The fair value of those businesses still exceeded their carrying value, and the results related to analyze for those businesses are in line with management's expectations given the recent date of the appraisal and purchase price allocation. Accordingly, step two of the impairment analysis was not required. The Company also performs a separate impairment test for each other intangible asset with an indefinite life, based on estimated future use and discounting estimated future cash flows. A considerable amount of management judgment and assumptions required in performing the impairment tests. Though management considers its judgments and assumptions to be reasonable, changes in economic or market conditions, product offerings or marketing strategies could change the estimated fair values and result in impairment charges (GRACO, 2015).

\section{Interpretation of Content Analysis Findings}

We must recognize this loss in the current period. If it is not possible to estimate the recoverable amount for an individual asset and then determine it for the cash-generating unit of which the asset is a part. However, this situation arises when the cash flow linked to an asset is negligible.

The impairment loss on a revalued asset as a revaluation decrease. Recognize this loss in other comprehensive income up to the amount of the revaluation surplus, and recognize any additional impairment as a loss. Following recognition of an impairment loss, adjust future depreciation charges to allocate an asset's revised carrying amount over its remaining useful life.

We do not reverse an impairment loss under U.S. GAAP because not permit. Under IFRS, we do reverse an impairment loss at the end of each reporting period, assess whether there is any indication that a previously recognized impairment loss (not including goodwill) either may have declined or no longer exists.

Use the following indicators to make the determination:

a) Favorable effects. There are or will be favorable effects involving the entity's business environment

b) Interest rates. Market interest rates have declined and will affect the discount rate used to determine the present value of cash flows associated with the asset

c) Internal improvements. The asset's usage or expectations for its use have changed, such as through efficiency improvements.

d) Market value. The asset's market value has increased

e) Usage period. The entity expects a longer performance period for the asset. 
We should remember that estimate the recoverable amount of the asset if one or more of these indicators have changed. It is allowable to reverse an impairment loss only if there is a change in the estimates used to determine the asset's recoverable amount.

If so, increase the carrying amount of the asset to its recoverable amount. The amount of the reversal cannot exceed what the asset's carrying amount (net of depreciation) would have no impairment originally recognize. We recognize the change in the current-period income statement. Once the impairment reversal is complete, adjust the asset's depreciation charge in future periods to allocate the revised carrying amount, less any residual value, over the remainder of its estimated useful life.

We cannot reverse a goodwill impairment loss under IFRS. If an impairment has already recognized for goodwill, it cannot reverse it in a subsequent period. It also cannot reverse an impairment loss recognized in a previous interim period. Of course, this would constitute the recognition of internally generated goodwill, which is not allowed.

\section{Recommendations for Future Study}

My finding emphasizes the importance of conservative accounting policies for measuring non-financial assets and the approach to impairment under IFRS and US GAAP. Accounting choices for non-financial assets under IFRS or US GAAP may not affect firms' investment decision, but could affect other important firms' decisions such as funding decisions. The researcher leaves that to future research studies.

\section{Conclusion}

The global accounting environment continues to change in dramatic ways, and all professionals must provide for a high standard of responsibility. The impairment losses and reversals should require several levels of approval in the company before being recognized. It is entirely possible that a lower-level accountant may calculate a need for a large number of small impairment charges and reversals, which a more senior accounting person with a better grasp of the efficiencies involved would be less inclined to approve. This should understand the impairment of assets under IAS 36 before our first IFRS adoption. Otherwise, there is a risk of overstating the assets listed on a multinational company's balance sheet, possibly by a large amount. In this article, the researcher addressed how to identify an impairment situation, how to calculate the amount of impairment, and the circumstances under which an impairment can reverse. The researcher observation can be a good source information for all professional management accountants in the United States before the first adoption the new IFRS in our company and help to switch from the current US GAAP requirements. Worldwide convergence is a whole process that will take time in to remove differences. In this terms, preparers, users, and auditors need to be aware that when it comes to IFRS - "convergence" doesn't always converge. As a consequence, the researcher suggests more research that investigates the long-lived consequences of the U.S.A. Adoption of IAS 36. This article should particularly address how impairments made under IAS 36 viewed by investors, how economic incentives drive the decision to impairment, and the increasingly important role the international auditors or management accountants play in verifying something almost unverifiable.

\section{References}

Andreea-Ioana, C., \& Pali-Pista, S. F. (2013). Harmonization of Financial Regulation and International Financial Reporting Standards - Particular Case of Noncurrent Assets. Annals of the University Of Oradea, Economic Science Series, 22(1), 1190-1197.

BEATTY, A., \& WEBER, J. (2010). Accounting Discretion in Fair Value Estimates: An Examination of SFAS 142 Goodwill Impairments. Journal of Accounting Research, 44(2), 257-288. http://dx.doi.org/10.1111/j.1475-679X.2006.00200.x

Camelia, U., \& Mariana, M. (2008). Der Werthaltigkeitstest (Impairment Test). Annals of the University Of Oradea, Economic Science Series, 17 (3), 1511-1517.

Chalmers, K., Clinch, G., Godfrey, J. M., \& Wei, Z. (2012). Intangible assets, IFRS and analysts' earnings forecasts. Accounting \& Finance, 52 (3), 691-721. http://dx.doi.org/10.1111/j.1467-629X.2011.00424.x

Computer Modelling Group Ltd. (2015). 10K - Annual Financial Statements. Security Exchange Commission.

Godfrey, J. M., \& Koh, P. (2010). Goodwill impairment as a reflection of investment opportunities. Accounting \& Finance, 49(1), 117-140. http://dx.doi.org/10.1111/j.1467-629X.2008.00272.x

Graco Inc. (2015). 10K - Annual Financial Statements. Security Exchange Commission. 
Hamberg, M., Paananen, M., \& Novak, J. (2011). The Adoption of IFRS 3: The Effects of Managerial Discretion and Stock Market Reactions. European Accounting Review, 20 (2), 263-288. http://dx.doi.org/10.1080/09638181003687877

HUIAN, M. C. (2013). Stakeholders' participation in the development of the new accounting rules regarding the impairment of financial assets. Business Management Dynamics, 2(9), 23-35.

Holman, D. L. (2004). CONVERGENCE: Hurdles Remain. Financial Executive, 20 (8), 32-34.

Komissarov, S., Kastantin, J. T., \& Rick, K. (2014). Impairment of Long-Lived Assets. CPA Journal, 84 (5), 28-33.

Kuzmina, I., \& Kozlovska, I. (2012). Accounting Measurement of Long-Lived Assets. Journal of Business Management, (5), 56-65.

Orzechowski, B., \& Lyster, P. (2012). Impairment Testing: Effectively Using the Qualitative Assessment. Journal of Accountancy, 214(6), 36-40.

Pozzoli, M., Romano, R., \& Romolini, A. (2011). Measurement and Impairment of Intangible Assets in the Italian Stock Exchange. Economia Aziendale Online $2000 \mathrm{Web},(1), 65-73$.

RIEDL, E. J. (2009). Discussion of "Regulatory Incentives for Earnings Management through Asset Impairment Reversals in China". Journal of Accounting, Auditing \& Finance, 24(4), 621-626.

Riedl, E. I. (2014). An Examination of Long-Lived Asset Impairments. Accounting Review, 79(3), 823-852. http://dx.doi.org/10.2308/accr.2004.79.3.823

Trottier, K. (2013). The Effect of Reversibility on a Manager's Decision to Record Asset Impairments. Accounting Perspectives, 12(1), 1-22. http://dx.doi.org/10.1111/1911-3838.12005

Yamamoto, T. (2008). Asset Impairment Accounting and Appraisers: Evidence from Japan. Appraisal Journal, 76(2), 179-188. 